\title{
COMPARISON OF THYROGLOBULIN CONCENTRATIONS MEASURED BY TWO IMMUNORADIOMETRIC ASSAY
}

\author{
Vesna Ignjatovic, Milovan Matovic, Vladimir Vukomanovic
}

University of Kragujevac, Serbia, Faculty of Medical Sciences, Department of Nuclear medicine

\author{
KORELACIJA KONCENTRACIJA TIREOGLOBULINA ODREĐENIH \\ KORIŠĆENJEM DVA IMUNORADIOMETRIJSKA TESTA \\ Vesna Ignjatović , Milovan Matović , Vladimir Vukomanović \\ Univerzitet u Kragujevcu, Kragujevac, Srbija, Fakultet medicinskih nauka, Katedra za nuklearnu medicinu,
}

\begin{abstract}
Circulating thyroglobulin measurements is a highly specific test in the management of patients affected by differentiated thyroid cancer after total thyroidectomy, followed by radioiodine ablation. The aim of our study was to compare two thyroglobulinimmunoradiometric assays (INEP, Serbia and Cisbio Bioassays, France). Study included 42 patients of both genders with DTC. The subjects were on suppres $\neg$ sive doses of levothyroxine and followed up. Results showed concordance between the two assay methods for determining serum thyroglobulin for 39 (92.85\%) patients. Statistical analysis showed that there was a direct correlation between two IRMA tests, with a positive correlation coefficient $r=0.613$ ( $p$ 0.05). We concluded that there is good agreement between the two thyroglobulin assays compared in this study.
\end{abstract}

Keywords: differentitated thyroid carcinoma, thyroglobulin, immunoradiometric assay.

\section{INTRODUCTION}

Differentiated thyroid cancer (DTC) is the most common endocrine malignancy $(1,2)$. Primary method for treatment of DTC is total or near-total thyroidectomy (1, 2). Radioiodine $\left.{ }^{(131} \mathrm{I}\right)$ ablation after total thyroidectomy is a usual procedure in patients with DTC, which is used to ablate the thyroid tissue remnants, the residual or recurrent thyroid cancer, and/or its local or distant metastases $(1,2)$. Since DTC originate from follicular thyroid cells, the malignantly transformed cells retain some functional characteristics of thyrocytes, depending on the degree of differentiation. Thus, they have receptors for thyroid-stimulating hormone (TSH) and they can produce thyroglobu$\operatorname{lin}(\mathrm{Tg})(1,2)$.

\section{ABSTRACT}

Merenje serumskog tireoglobulina je visokospecifičan test koji se koristi u praćenju pacijenata obolelih od diferentovanih karcinoma štitaste žlezde nakon totalne tireoidektomije praćene radiojodnom ablacijom. Cilj studije je poređenje koncentracija tireoglobulina dobijenih primenom dva imunoradiometrijska dijagnostička kompleta (proizvođača INEP, Srbija i Cisbio Bioassays, Francuska). Ispitivanjem su obuhvaćena 42 pacijenta oba pola koji su nakon totalne tireoidektomije zbog diferentovanog karcinoma štitaste žlezde lečeni radiojodnom terapijom. Svi pacijenti su bili na supresivnoj terapiji levotiroksinom i redovno su kontrolisani. Izvodenje obe analize je sprovedeno u skladu sa prospektom proizvođača. Rezultati su pokazali da postoji korelacija izmedu dva imunoradiometrijska testa za 39 (92,85\%) pacijenata. Statistička analiza je pokazala da postoji korelacija između oba imunoradiometrijska testa sa pozitivnim koeficijentom korelacije $r=0,613$. Na osnovu rezultata može se zaključiti da postoji značajan stepen slaganja u rezultatima dobijenim primenom dva imunoradiometrijska testa.

Ključne reči: diferentovani karcinom štitaste žlezde, tireoglobulin, imunoradiometrijski test.

After total or near total thyroidectomy, followed by radioiodine ablation serum thyroglobulin is a suitable marker for DTC following (1-4). Measurements of the serum concentration of thyroglobulin in patients with DTC serve as tumor marker, to evaluate the effectiveness of the applied treatment, detect residual disease and recurrence of disease in these patients (1-5).

Serum thyroglobulin is now generally measured by two-antibody "sandwich" immunometric assays (IMA), the antigen is sandwiched between the two antibodies, in which the capture antibody is bound to a solid support and the detection antibody is labeled with either an isotopic (immunoradiometric assay, IRMA) or non-isotopic (usual-

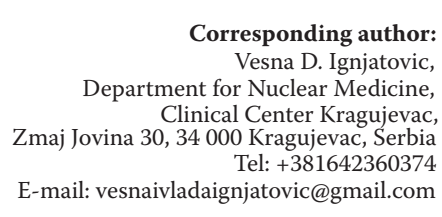

Corresponding author: ment for Nuclear Medicine, Clinical Center Kragujevac, Tel: +381642360374 E-mail: vesnaivladaignjatovic@gmail.com 
ly immunochemiluminescent assay) marker $(3,6)$. Secondgeneration) thyroglobulin immunometric assay measurements, have an higher functional sensitivity $(\leq 0.10 \mu \mathrm{g} / \mathrm{l})$ than older (first-generation) tests (functional sensitivity $\sim 1.0 \mu \mathrm{g} / \mathrm{l})(3,4,6)$. During follow-up low risic patients with DTC, blood samples are common taken for thyroglobulin measurement while the patient is taking L-thyroxine suppression (1-4). Therefore, thyroglobulin assays need second-generation functional sensitivity in order to monitor the low basal (non-TSH stimulated) thyroglobulin concentrations (3-4).

Unfortunately, the thyroglobulin autoantibodies (TgAbs) present in $25 \%$ to $30 \%$ of patients with DTCs can interfere with thyroglobulin measurement $(3,5)$. All of the immunometric assay methods were prone to underestimate serum $\mathrm{Tg}$ in the presence of $\mathrm{TgAb}$, whereas the radioimmunoassays methods appeared resistant to $\mathrm{TgAb}$ interference $(6,7)$. Radioimmunoassays are still in use because this competitive methodology appears to convey more resistance to $\mathrm{TgAbs}$ interference than other IMAclass tests, although some interfering $\operatorname{TgAbs}$ undoubtedly cause some falsely high or low serum thyroglobulin values $(7,8-10)$.

Considering the large differences in concentrations thyroglobulin that can be measured by different tests for the same serum samples, the aim of our study was to compare the concentrations thyroglobulin obtained using two radioimmunoassays of various manufacturers: Cisbio Bioassays (France), which has been used for several years in the Department of Nuclear Medicine, Clinical Center Kragujevac and new assay from INEP, Serbia which is the first time used in our laboratory.

\section{PATIENTS AND METHODS}

This study included 42 patients of both genders with DTC. All patients underwent total thyroidectomy and were treated with ${ }^{131} \mathrm{I}$ in order to ablate the remaining thyroid tissue. The subjects were on suppressive doses of levothyroxine $(\mathrm{TSH}<0.15 \mathrm{mIU} / \mathrm{L})$ and followed up. The study was conducted at the Department of Nuclear Medicine, Clinical Center Kragujevac. All blood samples were originally obtained for diagnostic purposes and studied in accordance with national ethical principles and in compliance with the Helsinki declaration. Blood $(10 \mathrm{~mL})$ from each patient was taken by venipuncture, and the serum separated by centrifugation at $2000 \mathrm{rpm}$ for 15 minutes. The sera were stored frozen at $-20^{\circ} \mathrm{C}$ and then thawed and all assayed together.

Serum concentrations of thyroglobulin were measured by immunoradiometric sandwich assay (IRMA) (THYROGLOBULINE, Cisbio Bioassays, France) according to the manufacturer's instructions. This assay uses an IRMA technique based on the following principle: five monoclonal TgAbs are used for the sandwich. The first four monoclonal antibodies are adsorbed onto the tube walls. Fifth
$\operatorname{TgAb}$ (125I-labeled) recognizing an epitope different from those recognized by the other four is used as the tracer. According to the manufacturer, the lower limit of detection was $0.2 \mu \mathrm{g} / \mathrm{L}$ and the calibration range was up to 500 $\mu \mathrm{g} / \mathrm{L}$. The functional sensitivity was $0.7 \mu \mathrm{g} / \mathrm{L}$. Intra-assay CV was $<7.0 \%$, and inter-assay CV was $<14.6 \%$. The assay was standardized against Certified Reference Material 457 (CRM 457).

Manufacturer of the second assay is INEP, Serbia. Concentration of thyroglobulin is determined by a immunoradiometric method using two clones of monoclonal antibodies specific to different epitopes on the thyroglobulin molecule. First monoclonal antibody is attached to the bottom of the tube and the second monoclonal antibody is labeled with the radioactive isotope of iodine ${ }^{125}$ I. According to the manufacturer, the lower limit of detection for this new assay was $0.1 \mu \mathrm{g} / \mathrm{L}$ and the calibration range was up to $200 \mu \mathrm{g} / \mathrm{L}$. Intra-assay CV was $<5.6 \%$, and inter-assay $\mathrm{CV}$ was $<5.9 \%$.

After incubation is completed, the contents of the tube are aspirated to remove unbound labeled antibodies, and the radioactivity in the bound complex is measured in a gamma counter. The amount of measured radioactivity is directly proportional to the concentration of $\mathrm{Tg}$ in the sample.

Serum thyroglobulin results were considered concordant if they were undetectable or detectable by both methods. Discordance was defined as being present when serum thyroglobulin was greater than $1 \mu \mathrm{g} / \mathrm{L}$ by one, but undetectable by the other assay.

The concentration of TgAbs was determined by a competitive "one-step" radioimmunoassay (TgAb I step) which has been used for several years in our department (Cisbio Bioassays, France). It is based on the competition type principle and carried out in human serum. In $\mathrm{TgAb}$ radioimmunoassay $\mathrm{TgAbs}$ in calibrators and diluted patient sera are allowed to interact with ${ }^{125} \mathrm{I} \mathrm{la}$ belled thyroglobulin. After a incubation and aspiration of the supernatant, the tubes are counted on a gamma counter. According to the manufacturer, the intra- and inter-assay precisions were less than $8.3 \%$ and $12.8 \%$, respectively. The method was calibrated against the World Health Organization (WHO) First International Reference Preparation CRM 65/93 and had an analytical detection limit of $6.0 \mathrm{IU} / \mathrm{mL}$. The manufacturer made no declaration about possible interference of thyroglobulin on antithyroglobulin measurements. The measured $\mathrm{TgAb}$ values were analyzed toward the value of $30 \mathrm{IU} /$ $\mathrm{mL}$ (cut-off for healthy subjects without thyroid disease as recommended by the manufacturer of the assay). Autoantibody concentrations higher than $30 \mathrm{IU} / \mathrm{mL}$ were considered "enhanced."

For statistical analysis we use the correlation analysis method (Pearson coefficient of correlation), the number of detectable Tg levels were compared by the chi-square test (SPSS 10.0 program). Results are graphically presented using the MS Excel application. 


\section{RESULTS}

In our study serum thyroglobulin concentrations were tested in 42 patients with DTC. Within regular follow-up a blood sample was taken for the determination of the thyroid hormones, thyroglobulin and antithyroglobulin antibodies in the radioimmunological laboratory of the Department of Nuclear Medicine, Clinical Center Kragujevac. Concentration of thyroglobulin is determined using two different radioimunoassay, the concentrations of the remaining laboratory parameters were determined by radioimmunoassays that are in regular use in our laboratory. The characteristics of the tests taken from the manufacturer's brochure are given in Table 1.

According to the manufacturer's brochure, the obtained thyroglobulin concentrations are expressed in $\mu \mathrm{g} / \mathrm{L}$ for both assays. The measured concentrations were within the range $<0.1$ to $87.0 \mu \mathrm{g} / \mathrm{L}$ (INEP), and $<0.2-46.7 \mu \mathrm{g} / \mathrm{L}$ (Cisbio). The thyroglobulin concentrations measured by Cisbio Bioassays and INEP assays were different in serum samples of 3 patients. In first case, high thyroglobulin values $(87.0 \mu \mathrm{g} / \mathrm{L})$ was measured by the INEP assay, while the Cisbio assay also detected an elevated thyroglobulin value, but almost twice less $(43.7 \mu \mathrm{g} / \mathrm{L})$. In the second case, a high concentration of thyroglobulin $(57.1 \mu \mathrm{g} / \mathrm{L}$ INEP) significantly differs from the concentration obtained for Cisbio thyroglobulin $(0.2 \mu \mathrm{g} / \mathrm{L})$. In the third case, Cisbio radioimmunoassay detected a high concentration of thyroglobulin $(46.7 \mu \mathrm{g} / \mathrm{L})$, while the concentration measured by the INEP radioimmunoassay was below the the limit of detection. The one patient had low, but measurable level of thyroglobulin in the range $0.2-0.6 \mu \mathrm{g} / \mathrm{L}$.

Concordance between the two assay methods for determining serum thyroglobulin levels was noted for 39 $(92.85 \%)$ patients. Statistical analysis showed that there was a direct correlation between two IRMA tests, with a positive correlation coefficient $r=0.613(\mathrm{p}<0.01)$. Using assays we have found that 38 patients had serum thyroglobu-

Table 1. The characteristic of two assays according to the manufacturers

\begin{tabular}{|ccc|}
\hline Parameters & IRMA Tg $($ INEP $)$ & $\begin{array}{c}\text { THYROGLOBULINE } \\
\text { IRMA } \\
\text { (Cisbio Bioassays) }\end{array}$ \\
\hline Principle of the assay & IRMA & IRMA \\
\hline Tracer & ${ }^{125} \mathrm{I}$ & ${ }^{125} \mathrm{I}$ \\
\hline Antibodies & monoclonal & monoclonal \\
Measuring range & $0.1-200 \mu \mathrm{g} / \mathrm{L}$ & $0.2-500 \mu \mathrm{g} / \mathrm{L}$ \\
Detection limit & $0.1 \mu \mathrm{g} / \mathrm{L}$ & $0.2 \mu \mathrm{g} / \mathrm{L}$ \\
\hline
\end{tabular}

Table 2. Agreement of serum thyroglobulin between the two assays

\begin{tabular}{|ccccc|}
\hline \multicolumn{4}{c}{ Thyroglobulin } \\
\hline & $<0.2 \mu \mathrm{g} / \mathrm{L}$ & $0.2-1 \mu \mathrm{g} / \mathrm{L}$ & $>1 \mu \mathrm{g} / \mathrm{L}$ & Number of patients \\
\hline $\begin{array}{c}\text { Thyroglobulin } \\
\text { INEP }\end{array}$ & 39 & 1 & 2 & 42 \\
\hline $\begin{array}{c}\text { Thyroglobulin, } \\
\text { CIS Bioassays }\end{array}$ & 39 & 1 & 2 & 42 \\
\hline
\end{tabular}

lin levels below the limit of detection by both methods and 2 patient had elevated serum thyroglobulin level by one of methods. Concentrations of thyroglobulin are given in Table 2. Statistical analysis of the results showed that the assays do not differ by separation of the pathological from the normal values $\left(x^{2}=3.841, \mathrm{p}>0.05\right)$.

In our study population two patients (4.33\%) had elevated levels of thyroglobulin antibodies $(57.7 \mathrm{IU} / \mathrm{mL}$ and $1049 \mathrm{IU} / \mathrm{mL}$ ). In the first patient (TgAbs $57.7 \mathrm{IU} / \mathrm{mL}$ ), both thyroglobulin assays found a low level of thyroglobulin, below the first standard concentration $(<0.2$ i.e. $<0.1 \mu \mathrm{g} / \mathrm{L})$. In the second patient, the concentration of TgAbs was high (1049 IU/mL), in this case, the Cisbio assay detected the high concentration of thyroglobulin $46 \mu \mathrm{g} / \mathrm{L}$ and INEP assay measured low concentration $(<0.2 \mu \mathrm{g} / \mathrm{L})$.

Statistical analysis showed a statistically significant positive correlation between the concentration of TgAbs and thyroglobulin Cisbio $\mathrm{p}<0.01$, the Pearson coefficient was 0.717 , but there is no statistically significant correlation between the concentration of TgAbs and second thyroglobulin assay.

\section{DISCUSSION}

Measurement of serum thyroglobulin is a highly specific test in the management of patients with DTC after surgical treatment and radioiodine ablation $(1,2)$. According to the guidelines $(1,2)$ serum thyroglobulin should be measured using a sensitive IRMA assay (functional sensitivity $<1.0 \mathrm{ng} / \mathrm{ml}$ ) standardized on the European reference standard (CRM 457) (3). Presence of TgAbs in the circulation may interfere with the assay, leading to false negative serum thyroglobulin determination. Increased concentrations of $\mathrm{TgAbs}$ are manifested in $20-30 \%$ of patients with DTC (4-6), so the presence of elevated TgAbs must be confirmed or ruled out by determining their concentration (4-6). Thyroglobulin is produced by both normal and neoplastic thyroid cells and its production is under TSH control $(1,2)$. Serum TSH should always be measured at the time of thyroglobulin determination (1-2). According to the guidelines, in the serum of our patient we measured concentration of thyroglobulin, TgAbs, thyroid hormones and TSH.

In clinical work with patients, the results are expressed as normal, low or high values, when we take into account the acquired values and the reference range. The highest percentage of our patients had a low concentration of thyroglobulin, below the lower limit of the measuring ranges. When comparing two assays, results are consistent for $92.85 \%$ patients. In literature data, the coefficient of correlation thyroglobulin measured by different tests is from 0.68 to $0.792(5,9)$. In our work the coefficient of correlation is slightly lower than in the previously mentioned literature and it is 0.613 .

Measurement of thyroglobulin in serum is technically difficult, associated with methodological problems, that 
can reduce the clinical significance of the obtained result. We find that the thyroglobulin concentrations measured by Cisbio Bioassays and INEP assays were quite differ-

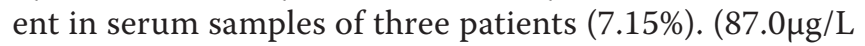
INEP vs. $43.7 \mu \mathrm{g} / \mathrm{L}$ Cisbio, $57.1 \mu \mathrm{g} / \mathrm{L}$ INEP vs. $0.2 \mu \mathrm{g} / \mathrm{L}$ Cisbio, $<0.2 \mu \mathrm{g} / \mathrm{L}$ INEP vs. $46 \mu \mathrm{g} / \mathrm{L}$ Cisbio). Many studies have shown that measured values for thyroglobulin differ depending on the test employed (4, 5, 10-12). Epitope mapping on the thyroglobulin molecule has shown the existence of six different antigenic regions to which different TgAbs can bind $(9,10)$. In our first assay (Cisbio) four monoclonal antibodies are adsorbed onto the tube walls and fifth antibody ( ${ }^{125}$ I-labeled) recognizing an epitope different from those recognized by the other four is used as the trace. In the second assay first monoclonal antibody is attached to the bottom of the tube and the second monoclonal antibody is labeled with the radioactive isotope ${ }^{125} \mathrm{I}$. So, this differences in individual concentrations of thyroglobulin measured in our study could be due to the different specificity of the antibodies directed at thyroglobulin used in assays. Subtle variations thyroglobulin concentration was observed in one case (i.e. $0.3 \mu \mathrm{g} / \mathrm{L}$ using the INEP vs $0.6 \mathrm{ng} / \mathrm{mL}$ using the Cisbio). These differences were clinically acceptable. No reference values have been established for measuring thyroglobulin during substitution therapy with thyroid hormones. Group of authors suggested that for patients who have undergone total or near-total thyroidectomy and radioiodine ablation and have no clinical evidence of residual tumor serum thyroglobulin should be below $1 \mu \mathrm{g} / \mathrm{L}$ during thyroid hormone suppression (17).

Before our results were interpreted, it should be noted that all the values for thyroglobulin and TgAbs in sera from DTC patients were obtained and we considered our results for thyroglobulin concentration in parallel with the concentration of TgAbs. One patient had significantly elevated level of TgAbs (1049 IU/mL), second patient had slightly elevated level od TgAbs (57.7 $\mathrm{IU} / \mathrm{mL}$ ). In the first patient, with slightly elevated $\mathrm{TgAb}$ $(57.7 \mathrm{IU} / \mathrm{mL})$, both thyroglobulin assays found a low level of thyroglobulin, below the first standard concentration $(<0.2$ i.e. $<0.1 \mu \mathrm{g} / \mathrm{L})$. On the contrary, in the second patient with the high concentration of TgAbs (1049 IU/ $\mathrm{mL}$ ), the Cisbio assay showed a considerable elevation of serum ratio of thyroglobulin but INEP assay measured low concentration thyroglobulin $(46 \mu \mathrm{g} / \mathrm{L}$ vs. $<0.2 \mu \mathrm{g} / \mathrm{L})$. Two different results can be explained by the effect of elevated concentration of anti-thyroglobulin antibodies. The presence of $\operatorname{TgAbs}$ leads to over- or underestimation of thyroglobulin concentrations with different degrees among assays $(7,8,18)$. Radioimmunoassays methods appears more resistant to $\mathrm{TgAbs}$ interference than IMA-class tests $(7,19,20)$. RIA is relatively resistant to interference from $\operatorname{TgAbs}(4,7,8)$, and some authors have observed good correlation among different immunoradiometric assays (15).

\section{CONCLUSIONS}

There is good agreement between the two thyroglobulin assays compared in this study. The new INEP IRMA thyroglobulin is a sensitive assay for thyroglobulin measurement, and the results were highly correlated with those obtained with the Thyroglobulin Cisbio Bioassays.

\section{Conflicts Of Interest}

The authors declare no conflict of interest.

\section{REFERENCES}

1. Cooper DS, Doherty GM, Haugen BR, et al. (2009). Revised American Thyroid Association management guidelines for patients with thyroid nodules and differentiated thyroid cancer. Thyroid, 19:1167-1214.

2. Pacini F, Schlumberger M, Dralle H, et al. (2006). European consensus for the management of patients with differentiated thyroid carcinoma of the follicular epithelium. Eur J Endocrinol, 154:787-803.

3. Feldt-Rasmussen U, Profilis C, Colinet E, et al. (1996). Human thyroglobulin reference material (CRM 457). 1st part: assessment of homogeneity, stability and immunoreactivity. Annales de Biologie Clinique Paris, 54:337-342.

4. Stanojevic M, Savin S, Cvejic D, et al. (2009). Correlation of thyroglobulin concentrations measured by radioimmunoassay and immunometric assay and the influence of thyroglobulin antibody. J Immunoassay Immunochem, 30:197-207.

5. Stanojevic M, Savin S, Cvejic D, et al. (2009). Comparison of the influence of thyroglobulin antibodies on serum thyroglobulin values from two different immunoassays in post surgical differentiated thyroid carcinoma patients. J Clin Lab Anal, 23:341-346.

6. Görges R, Maniecki M, Jentzen W, et al. (2005). Development and clinical impact of thyroglobulin antibodies in patients with differentiated thyroid carcinoma during the first 3 years after thyroidectomy. Eur J Endocrinol,153:49-55.

7. Spencer CA, LoPresti JS. (2008). Technology insight: Measuring thyroglobulin and thyroglobulin autoantibody in patients with differentiated thyroid cancer. Endocrinol Metab,4:223-233.

8. Spencer CA, Bergoglio LM, Kazarosyan M, et al. (2005). Clinical impact of thyroglobulin (Tg) and Tg autoantibody method differences on the management of patients with differentiated thyroid carcinomas. J Clin Endocrinol Metab, 90:5566-5575.

9. Cheng X, Yu S, Jin C, Han S, et al. (2017). Comparison of three different assays for measuring thyroglobulin and thyroglobulin antibodies in patients with chronic lymphocytic thyroiditis. Clinical Biochemistry, 50(18):1183-1187. 
10. Giovanella L, Clark P, Chiovato L, et al. (2014). Thyroglobulin measurement using highly sensitive assays in patients with differentiated thyroid cancer: a clinical position paper. Eur J Endocrinol, 171:R33-R46

11. Netzel BC, Grebe SKG, Carranza Leon BG, et al. (2015). Thyroglobulin (Tg) Testing Revisited: Tg Assays, TgAb Assays, and Correlation of Results With Clinical Outcomes. The Journal of Clinical Endocrinology and Metabolism, 100(8):E1074-E1083. doi:10.1210/jc.2015-1967.

12. Schlumberger M, Hitzel A, Toubert ME, et al. (2007). Comparison of seven serum thyroglobulin assays in the follow-up of papillary and follicular thyroid cancer patients. J Clin Endocrinol Metab, 92:2487-2495.

13. Okosieme OE, Evans C, Moss L, et al. (2005). Thyroglobulin antibodies in serum of patients with differentiated thyroid cancer: relationship between epitope specificities and thyroglobulin recovery. Clin Chem, 51(4):729-734.

14. Estienne B, McIntosh RS, Ruf J, et al. (1998). Comparative mapping of cloned human and murine antithyroglobulin antibodies: recognition of human antibodies of an immunodominant region. Thyroid, 8: 643-648.

15. Lee JI, Kim JY, Choi JY, et al. (2010). Differences in serum thyroglobulin measurements by 3 commercial immunoradiometric assay kits and laboratory standardization using Certified Reference Material 457 (CRM-457) Head Neck, 32:1161-1166.
16. Spencer C, Fatemi S. (2013). Thyroglobulin antibody ( $\operatorname{Tg} \mathrm{Ab}$ ) methods -Strengths, pitfalls and clinical utility for monitoring TgAb-positive patients with differentiated thyroid cancer. Best Pract Res Clin Endocrinol Metab, 27:701-712.

17. Mazzaferri EL, Robbins RJ, Spencer CA, et al. (2003). A consensus report of the role of serum thyroglobulin as a monitoring method for low-risk patients with papillary thyroid carcinoma. J Clin Endocrinol Metab, 88(4):1433-1441.

18. Vrndic O, Savin S, Mijatovic Lj, et al. (2011). Concentration of Thyroglobulin and Thyroglobulin-Specific Autoantibodies in Patients With Differentiated Thyroid Cancer After Treatment With Radioactive Iodine 131, Lab Medicine, 42(1):27-31

19. Cho YY, Chun S, Lee S-Y, et al. (2016). Performance Evaluation of the Serum Thyroglobulin Assays With Immunochemiluminometric Assay and Immunoradiometric Assay for Differentiated Thyroid Cancer. Ann Lab Med, 36(5):413-419. doi:10.3343/alm.2016.36.5.413.

20. Spencer C, LoPresti J, Fatemi S. (2014). How sensitive (second-generation) thyroglobulin measurement is changing paradigms for monitoring patients with differentiated thyroid cancer, in the absence or presence of thyroglobulin autoantibodies. Curr Opin Endocrinol Diabetes Obes,21(5):394-404. doi: 10.1097/ MED.0000000000000092. 